\title{
PERBAIKAN SKALA USAHA SAPI POTONG PADA KELOMPOK PETERNAK MALINGPING DAN HASANAH DI KABUPATEN SUKABUMI
}

\author{
S. Rusdiana, L. Praharani dan D.A. Kusumaningrum \\ Balai Penelitian Ternak Ciawi, PO.Box. 221. Bogor-Jawa Barat \\ E-mail : supardirusdiana@pertanian.go.id
}

\begin{abstract}
The purpose of this study was to determine the improvement of beef cattle business scale in Mmalingping and Hasanah breeders in Sukabumi Regency. The study was conducted on a group of beef cattle farmers in Purabaya District, Sukabumi Regency, West Java Province, in 2016. With a structured interview survey method for a group of Malingping beef cattle breeders by purposive random sampling as many as 18 farmers, and the Hasanah breeders group of 18 farmers. Each group of breeders is divided into 2 (two) parts, namely group I maintains beef cattle on a 2-3-scale scale and group II maintains beef cattle on a scale of 4-6 head. The research data is then tabulated by descriptive, quantitative and financial economic analysis of the $B / C$ ratio. The results of the financial economic analysis of the net profit in the breeders of Malingping beef cattle from the maintenance of 2 mains to 3 mains of IDR $2,078,000 / y e a r$ to IDR 5,799,500/years, or an increase of $65.13 \%$, B/C ratio 1.06 1.12. The net profit in the Hasanah beef cattle breeders group from 2 parent scale maintenance to 3 parent head scale is IDR 2,384,000/year to be IDR 5,009,250/year, or an increase of 64.18\%, B/C ratio 1.05-1.10. If the Malingping and Hasanah beef cattle breeders maintain a scale of $>3$ productive female mothers, it is very economical, effective and efficient, economically beneficial.
\end{abstract}

Keywords: analysis, scale improvement of beef cattle business

\begin{abstract}
Abstrak: Tujuan penelitian ini adalah untuk mengetahui perbaikan skala usaha sapi potong pada kelompok peternak Malingping dan Hasanah di Kabupaten Sukabumi. Penelitian dilakukan pada kelompok peternak sapi potong di Kecamatan Purabaya Kabupaten Sukabumi, Propinsi Jawa Barat, pada tahun 2016. Dengan metoda survei wawancara terstruktur terhadap kelompok peternak sapi potong Malingping secara purposive random sampling sebanyak 18 peternak, dan kelompok peternak Hasanah 18 peternak. Setiap kelompok peternak dibagi menjadi 2 (dua) bagian, yaitu kelompok I memelihara sapi potong dengan skala 2-3 ekor dan kelompok II memelihara sapi potong dengan skala 4-6 ekor. Data hasil penelitian kemudian ditabulasi dengan cara deskritif, kuantitatif dan analisis ekonomi finansial B/C ratio. Hasil analisis ekonomi finansial keuntungan bersih pada kelompok peternak sapi potong Malingping dari pemeliharaan skala 2 ekor induk menjadi 3 ekor induk sebesar Rp 2.078.000/tahun menjadi sebesar Rp 5.799.500/ tahun, atau naik sebesar 65,13\%, B/C ratio 1,06-1,12. Keuntungan bersih pada kelompok peternak sapi potong Hasanah dari pemeliharaan skala 2 ekor induk menjadi skala 3 induk ekor sebesar Rp 2.384.000/tahun menjadi sebesar Rp5.009.250/ tahun, atau naik sebesar 64.18\%, B/C raio 1,05-1,10. Bila kelompok peternak sapi potong Malingping dan Hasanah memelihara skala $>3$ ekor induk betina produktif, sangat ekonomis, efektif dan efisien, secara ekonomi dapat menguntungkan.
\end{abstract}

Kata kunci: analisis, perbaikan skala usaha, sapi potong 


\section{PENDAHULUAN}

Kemandirian kelompok peternak Malingping dan Hasanah sudah berpengalaman, dalam pengelolaan usaha sapi potong. Pengalaman peternak diantarany cara memilih ternak untuk bibit, penyediaan pakan, perkandangan, penyakit, pengelolaan reproduksi, pascapanen, dan pemasaran hasil. Kelompok peternak sapi potong di Kecamatan Purabaya Kabupaten Sukabumi diarahkan oleh Dinas Peternakan setempat kedalam usaha yang bersipat komersial, atau kedalam usaha pokok. Biasnya peternak dalam kepemilikan sapi potong antara 2-3 ekor/peternak. Demikian terbukti dapat meningkatkan kesejahteraan peternak, disamping usaha tanaman pangan (Rusdiana $e t$ al., 2010). Peternak sangat perlu dukungan dari para penyuluh dan lembaga lainnya, agar peternak dapat mengubah pola usaha tradisional menjadi pola komersial (Suryana, (2010). Menurut Ahmad (2004) pemeliharaan ternak sapi potong sangat banyak diminati oleh kelompok peternak kecil, karena ternak sapi dapat dipelihara dengan teknologi yang sederhana, dan juga hasilnya dapat meningkatkan pendapatan petani.

Kelompok peternak sapi potong cara usaha pemeliharaannya dilakukan dengan cara intensif dan semi intensif. Dimana penyediaan pakan dilakukan oleh peternak (cut and carry), dan dengan cara digembalakan dilahan penggembalaan. Analisis ekonomi pada usaha ternak sapi potong secara intensif dan semi intensif, perlu di perhitungan ekonomi secara rill, agar keuntungan dapat diketahui dengan benar (Rusdiana dan Soeharsono 2017b). Pentingnya memperhitungkan biaya untuk usaha ternak sapi potong di kelompok peternak, agar peternak dapat memaksimalkan biaya produksinya. Untuk keberhasilan dan kelancaran usaha ternak sapi potong dapat di analisis dengan secara ekonomi B/C ratio. Sapi potong yang dipelihara oleh kelompok peternak Malingping dan Hasanah merupakan bagian dari kehidupan sehari-hari. Secara sosial dan budaya, meningkatkan derajat kehidupan kelompok peternak sapi potong. Kenyataan dilapangan bahwa umumnya usaha peternakan sapi potong masih banyak diusahakan dengan cara sederhana.

Usaha ternak sapi perah sangat perlu diupayakan usahanya melalui introduksi inovasi teknologi peternakan, yang sesuai dengan kondisi dan situasi lingkungan wilayah pedesaan. Menurut Dwiyanto, (2008) dan Rusdiana et al., (2016a) bahwa, untuk memenuhi kebutuhan pakan ternak berbagai usaha telah banyak dilakukan seperti integrasi padi ternak, pemanfaatan lahan perkebunan kelapa dan perkebunan. Menurut Dewi dan Mairika, (2008) bahwa, vegetasi alami hijauan pakan ternak yang tumbuh disembarang tempat, mempunyai nilai ekonomis cukup baik. Kebutuhan hijauan pakan ternak, perlu diketahui perkembangan usaha ternak sapi potong, baik pada usaha besar maupun kecil, agar kemajuan usaha tetap berjalan. Ternak sapi potong yang dipelihara oleh setiap kelompok peternak, dan mempunyai nilai jual yang tinggi, akan mempengaruhi nilai perekonomiannya meningkat. Semakin banyak ternak sapi potong yang dipelihara oleh setiap kelompok peternak, maka akan semakin banyak pula keuntungan yang akan diterima oleh peternak (Riszqina et al. 2011).

Untuk merekomendasikan angka yang sebenarnya dapat dianalisis secara estimasi atau perkiraan keuntungan pada usaha ternak sapi potong di kelompok peternak Malingping dan kelompok peternak Hasanah. Diharapkan kelompok peternak sapi potong dapat memprediksi keuntungan dari hasil penjualan ternak sapi potong dan keuntungan yang akan diperoleh pada akhir tahun erhitung dengan jelas apakah untung atau rugi dapat dihitung dengan secara analisis B/C ratio. Kelayakan usaha sapi potong bisanya dioptimalkan oleh peternak, seperti biaya tenaga kerja, biaya pakan. Berdasarkan permasalah tersebut diatas, diharapkan kelompok peternak sapi potong Malingping dan Hasanah mendapat keuntungan yang optimal. Selama ini kelompok peternak sapi potong keuntungan yang diperoleh belum maksimal, dan belum sesuai dengan harapan peternak. Tujuan penelitian ini adalah untuk mengetahui perbaikan skala usaha sapi potong pada kelompok peternak malingping dan hasanah di Kabupaten Sukabumi.

\section{METODE PENELITIAN}

\section{Dasar Pertimbangan}

Dasar pertimbangnya kelompok peternak sudah berpengalaman dalam mengelola usaha ternak sapi ptong. Pemerintahan di Kecamatan 
Purabaya Kabupaten Sukabumi sangat mendukung peternak dalam usaha ternak sapi potong. Menurut Rusdiana dan Praharani (2015), peternak sapi potong dalam melakukan usaha secara diversifikasi dengan usaha tanaman pangan dan usaha dagang. Kegiatan usaha yang paling banyak dipilih oleh masyarakat pedesaan salah satunya di Kabupaten Sukabumi adalah usaha pertaian dan peternakan. Usaha diversifikasi tanaman pangan dan ternak akan mendapatkan keuntungan dangan waktu yang bersamaan. Ternak sapi potong dapat distribusikan sebagai sumber daya yang dapat diperbaharui untuk menghasilkan keuntunagn bagi peternak. Mengingat ketersediaan lahan dan sumberdaya manusia peternak yang relatif cukup, sehingga perlu diusahaan dengan baik. Pembentukan kelompok peternak yang berorientasi pada agroindustri hulu dan hilir, sudah tersedia di lokasi Kabupaten Sukabumi.

Sarana dan prasarana lingungan di sekitar wilayah Kabupaten Sukabumi khususnya di Kecamatan Purabaya sudah dapat dimanfaatkan sebagai peluang usaha bagi peternak. Ternak sapi potongg mempunyai nilai komersial yang cukup tinggi, dan dapat diandalkan untuk memenuhi kebutuhan finansial peternak secara mendadak (Adawiyah dan Rusdiana 2016). Usaha ternak sangatlah mengiurkan, karena ternak sapi potong memiliki taksiran harga jualnya yang cukup tinggi, bila menjelang hari-hari besar keagamaan. Permintaan pasar untuk kebutuhan daging sapi akan semakin meningkat, sesuai dengan pertambahan jumah penduduk dan nilai pendapatan per kapita di masyarakat cukup tinggi dan beragam. Membuat banyak orang ingin sekali usaha memelihara ternak sapi potong, khusuny pada ternak jantan. Pertimbangan peternak untuk usaha ternak sapi potong, tidak memerlukan lahan luas dan modal besar untuk usaha.

Meskipun usaha ternak sapi potong salah satu yang menjadi dominan bagi semua masyarakat di Indonesia, namun usaha pokoknya adalah usaha pertanian. Semakin meningkat pendapatan masyarakat, akan pengetahuan tentang kebutuhan gizi pangan, serta perubahan selera masyarakat, cenderung mengarah pada kebutuhan protein hewani (Ilham et al., 2008). Percepatan pengembangan pertanian dan peternakan sebagai suplai bahan pangan dalam upaya mencukupi kebutuhan pangan secara nasional dapat terpenuhi dengan baik (Muzayyanah et al., 2016). Upaya kemandirian dan kecukupan akan pangan asal hewani menjadi program Pemerintah yang paling utama (Adawiyah et al., 2016). Saat ini sektor pertanian, termasuk subsektor peternakan di perdesaan, mampu menciptakan lapangan usaha sebear $3,23 \%$ dengan penyerapan tenaga kerja sebanyak 35,54 juta orang (Kementerian Pertanian 2015).

Usaha ternak sapi potong merupakan peluang usaha yang tersedia dilokasi, dan sebagai upaya untuk meningkatkan pendapatan selain sumber pendapatan pokok dari kegiatan usaha tani lainya (Gustimulyanti et al., 2016). Modal besar dan kecil dapat dipertimbangkan dengan kemampuan para kelompok peternak. Input kandang ternak sapi potong dapat dibangun dengan bahan yang sederhana, dan dapat disediakan secara lokal dan murah. Pakan ternak sapi potong juga, sebagai input utama yang dapat disediakan setiap hari. Pakan hijaun dan limbah hasil pertanian sudah tersedia dan dapat dimanfaatkan sebagai pakan ternak sapi potong.

\section{Pendekatan Penelitian}

Koordinasi secara vertikal terus dilakukan dengan unit kerja Dinas Pertanian dan Peternakan Kabupaten Sukabumi, merupakan unit pengelola teknologi inovasi pada usaha tanaman pangan dan ternak sapi potong. Koordinasi tersebut dilakukan secara horisontal, dan tujuannya untuk menjembatani koordinasi teknis dengan Dinas dan peternak. Tentunya juga dilakukan pada institusi-institusi yang secara herarkhi mempunyai fungsi koordinatif dengan kelompok peternak sapi potong. Dinas sebagai partner kerja, dan merupakan sumber inspirasi dalam meramu solusi secara teoritis. Kelompok peternak sapi potong mempunyai peluang pelaksanaan lebih realistis dan sustainabilitas yang tinggi pada usaha ternak sapi potong. Vertikal dan horisontal diharapkan dapat meningkatkan efisiensi tenaga dan biaya pelaksanaan di lokasi-lokasi yang terpilih untuk menerima program sapi potong di kawasan pengembangannya. Pada aspek teknis usaha ternak sapi potong, dapat dilihat dari kriteria kelayakan usahanya (Rusdiana et al., 2016a). 
Ternak sapi potong yang diberikan kepada kelompok peternak diharapakan dapat menghasilkan keuntungan yang sepadan dengan kemampuan peternak. Ternak sapi potong yang dipelihara oleh setiap kelompok peternak sebagai cara usahanya agar, benarbenar diusahakan dengan baik. Ternak sapi potong selain dapat dimanfaatkan sebagai penyadia daging sapi bagi masyarakat juga dapat dijual mendadak pada saat peternak butuh uang. Ternak sapi potong dalam pengembangannya dapat dintergrasikan dengan komoditas pertanian dan lainnya. Dirjen PKH (2016), untuk mencapai target populasi sapi potong betambah, telah membuat terobosan baru, melalui program Sapi Induk Wajib Bunting (Siwab). Pengembangan inovasi teknologi tersebut dapat dikembangkan di peternak. Inovasi secara spesifik lokasi yang mengarah pada usaha agribisnis peternakan. Untuk jaringan pasar hasil produksi pertanian dan peternakan di Kabupaten Sukabumi cukup baik, karena kondisi lingkungan peternakan sangat strategis dengan pasar.

Sebelum penelitian dimual digunakan survei lapang dengan menggunakan Focal Group Discussion (FGD) yang dipokuskan kepada penanggung jawab program inpormasi dan kesehatan hewan dari Dinas Peternakan dan Peternakan Kabupaten Sukabumi. Diskusi melalui FGD dilakukan pada tingkat perencana di lingkup Dinas/Instansi terkait di Kabupaten Sukabumi. Iklim sangat daan sikap masyarajat setemmpat sangat mendukung untuk perkembangan usaha ternak sapi potong. Program Kementerian Pertanian (2018) bahwa, pembangunan pertanian dalam Rencana Strategis 2015-2019 untuk meningkatkan pendapatan dan kesejahteraan peternak. Rencana kedepan usaha ternak sapi potong, dapat diperluas dalam pengembangan usahanya. Pasar sayuran di Kabupaten Sukabumi buka setiap hari, dan pasar ternak dibuka dalam 1 minggu 3 kali, senin, rabu dan jumat. Namun pasar ternak dapat dibuka setiap waktu, karena hampir semu masyarakat di Kecamatan Purabaya usahanya bertani dan beternak. Lokasi pasar ternak sangat strategis dan mudah terjangku, sehingga konsumen ternak tidak mengalami kesulitan transaksi jual beli ternak.

\section{Pendekatan Masalah}

Di wilayah Kecamatan Purabaya Kabupaaten Sukabumi Propinsi Jawa Barat, pada dasarnya hampir semua peternak memelihara ternak sapi potong, tujuannya untuk mendapatkan keuntungan. Selama ini peternak belum mendapaatkan keuntungan yang layak, ditnjau dari usahanya masih bersifat sampingan dan tambungan. Kelompok peternak sapi potong di Kecamatan Purabaya dalam pemeliharananya hampir sama yaitu, pembesaran pedet, penggemukan, pembibitan dan mendapatkan anak sapi. Untuk meningkatkan keuntungan yang layak, maka pengeluaran biaya pakan, peternak selalu memanfaattkan pakan lokal. Kawasan Kecamata Purabaya lahan kosong dapat digunakan untuk penggembalaan ternak sapi potong. Namun sebagian kelompok peternak cara pemeliharaannya dikandangkan dan digembalakan dan ikat pindah. Hijauan pakan ternak sapi potong dikawasan lingkungan pemukiman penduduk masih dapat mendukung untuk perkembangan sapi potong.

Dukungan lahan diantaranya adalah lahan perkebunan kelapa, karet, pertanian, lahan kosong tegalan yang belum tergarap oleh pemiliknya dan lahan sawah. Peternak mudah mencari pakan, baik pada saat musim kemarau, musim hujan dan pada saat-saat lainnya. Selain dukungan lahan sebagai tempat pertumbuhan hijauan pakan ternak juga didukung dengan ketersediaan tenaga kerja peternak. Dewi et al., (2010) menyatakan bahwa, pengembangan sumber daya manusia merupakan proses untuk meningkatkan pengetahuan, kreativitas dan keterampilan peternak dalam meningkatkan usahanya. Hal tersebut sangat penting, bagi peternak dan kaitannya dengan penerimaan aplikasi inovasi teknologi. Teknologi gunanya untuk mendukung keberhasilan usaha ternak sapi potong, untuk mencapai keuntugan peternak yang optimal. (Rusdiana et al., 2018). Untuk dapat mengadopsi teknologi, maka peternak diperlukan pelatihan dan pengalaman beternak.

Sebagian peternak belum pernah mengikuti pelatihan cara usaha ternak sapi potong. Disamping itu pula kesempatan peternak untuk mengikuti pelatihan belum ada, karena informasi dan tidak sempat. Kegiatan usaha tani ternak, sumber daya manusia, tenaga kerja peternak sangat dibutuhkan sehingga dapat mengimbangi dalam melakukan 
usahanya (Dinas Pertanian dan Peternakan Kabupaten Sukabumi 2017). Usaha pertanian maupun ternak menjadi tulang punggung sumber penghidupan bagi mayoritas masyarakat peternak di Kecamatan Purabaya Kabupaten Sukabumi. Implikasinya, bahwa usaha ternak sapi potong dapat meningkat pendapatan peternak, dan didukung dengan sarana prasarana yang memadai untuk kelancaran usaha ternak.

\section{Waktu dan Tempat Penelitian}

Penelitian dilakukan pada kelompok peternak sapi potong di Kecamatan Purabaya Kabupaten Sukabumi, Propinsi Jawa Barat, pada tahun 2016. Pemilihan lokasi penelitian dilakukan sesuai dengan kriteria, luas lahan pertanian dan populasi ternak sapi potong. Lokasi penelitian adalah mewakili hamparan pertanian, lahan perkebunan, lahan kosong milik petani, lahan milik perhutani, Survei lapang dilakukan melalui wawancara dan pengisian kuisioner berstruktur terhadap kelompok peternak sapi potong Malingping secara purposive random sampling sebanyak 18 peternak, dan kelompok peternak Hasanah 18 peternak. Pada setiap kelompok peternak sapi potong dibagi menjadi 2 (dua) bagian, yaitu kelompok I peternak yang memelihara sapi potong dengan skala 2-3 ekor dan kelompok II peternak yang memelihara 4-6 ekor. Kelompok peternak sapi potong Malingping dan Hasanah berdiri sejak tahun 2009.

Pemberian pakan hijauan untuk ternak sapi potong yang dipelihara secara intensif maupun ektensif (ed libitum). Pada saat peternak mengolah lahan pertanian sendiri, dan pada waktu peternak mau pulang, peternak biasanya mencari hijauan pakan atau rumput (Rusdiana dan Adawiyah 2013). Biaya pengeluaran untuk pakan dapat dikurangi, pakan yang diperoleh peternak disesuaikan dengan jumlah sapi yang dipelihara. Untuk melihat seberapa besar keuntungan yang diperoleh di masing-masing kelompok peternak Malingping dan kelompok peternak Hasanah. Nilai keuntungan dapat diprediksi dengan menilai jumlah ternak yang dipelihara dan yang dijual, nilai harga jual/ekor/tahun (Rusdiana and Soeharsono 2017). Pada kelompok I skala 2-3 ekor/peternak dan kelompok II skala 4-6 ekor/peternak menghitung proporsi nilai bibit ternak yang dipelihara dengan skala 2-3 ekor induk. Rata-rata umur ternak antara 1-2 tahun, dengan bobot badan ternak sapi potong sebesar 200-220 kg/ekor pada setiap kelompok peternak Malingping dan Hasanah.

\section{Analisis Data}

Data primer diperoleh melalui hasil wawancara langsung dilapangan dengan responden, yang mengacu kepada kuisioner yang telah disiapkan. Data sekunder diperoleh dari Dinas Pertanian dan Peternakan Kabupaten Sukabumi. Data dukung hasil penelitan yang telah dilaporkan dan dari informasi yang terkait sesuai dengan judul penelitian, serta dari ideide pemikiarn sendiri. Data yang dikumpulkan hasil penelitian survei lapang, ditabulasi dan dianalisis secara deskritif, kuantitatif dan analisis ekonomi B/C, (Atmakusuma et al. 2014) dan (Rusdiana et al., 2016a).

\section{HASIL DAN PEMBAHASAN}

\section{Tinjauan Umum Wilayah}

Wilayah Kabupaten Sukabumi Propinsi Jawa Barat, dengan luas wilayah $4.128 \mathrm{~km}^{2}$, dan merupakan Kabupaten terluas kedua di Pulau Jawa. Batas wilayah Kabupaten Sukabumi sebesar $40 \%$, berbatasan dengan lautan sebesar $60 \%$ merupakan daratan. Kabupaten Sukabumi memiliki areal yang relatif luas yaitu \pm 419.970 ha, tahun 2016, tata guna tanah di wilayah Kabupaten Sukabumi sebagi berikut: Pekarangan atau perkampungan sebesar 18.814 ha atau sebesar 4,48\%, sawah seluas 62.083 ha atau sebesar $14,78 \%$, tegalan 103.443 ha atau sebesar 24,63\%, perkebunan seluas 95.378 ha atau sebesar $22,71 \%$, danau atau kolam selus 1. 486 ha atau sebesar $0,35 \%$, hutan seluas 135.004 ha atau sebesar 32,15\%, dan penggunaan lainnya 3.762 ha atau sebesar $0,90 \%$ (Dinas Pertanian dan Peternakan Kabupaten Sukabumi Propinsi Jawa Barat. 2016)

\section{Karakteristik Kelompok Peternak Sapi Potong}

Hasil penelitian menunjukkan bahwa, karakteristik kelompok peternak ternak sapi potong pada kelompok peternak Malingping dan Hasanah, dengan pendidikan rata-rata SD dan tidak tamat SD. Mengidentifikasikan bahwa tingkat pengetahuan peternak masih rendah, dengan demikian dibutuhkan 
pendidikan non formal untuk peternak. Gunanya untuk meningkatkan pengetahuan peternak sapi potong di kelompok Malingping dan Hasanah, agar cara usahanya betul-betul sudah mengarah ke uasha komersial. Demikian kelompok peternak sapi potong tetap bersemangat dalam usaha ternaknya. Pekerjaan utama dari masing-masing kelompok peternak Malingping dan Hasanah adalah usaha bertani dan ternak. Rata-rata karakteristik dari masingmasing kelompok peternak sapi potong terlihat pada Tabel.1.

Tabel.1, terlihat bahwa, umur peternak hampir sama, baik pada kelompok peternak Malingping dan Hasanah. Rata-rata umur peternak Malingping antara 44,67 \pm 0,34$44,78 \pm 0,32$ dan rata-rata umur kelompok peternak Hasanah antara 44,56 \pm 0,28$44,88 \pm 0,17$. Rata-rata pengalaman beternak kelompok Malingping antara 22.31 $\pm 0,10$ $22,31 \pm 0,10$ dan Hasanah antara $22,43 \pm 0,10$ $22,31 \pm 0,03$. Artinya umur peternak masih produktif dan ditunjang dengan pengalaman beternak cukup lama. Peternak masih dapat menerima sentuhan teknologi, untuk pusaha ternak sapi potong. Tenaga kerja kelompok peternak Malingping digunakan untuk usaha pemeliharaan ternak sapi potong antara $1,0 \pm 0,05-1,1 \pm 0,04$ dan kelompok peternak Hasanah antara $1,0 \pm 0,05-1,3 \pm 0,04$. Rata-rata lahan yang dimiliki oleh setiap kelompok peternak Malingping antara 0,42 $\pm 0,18$ $0,43 \pm 0,02$ dan kelomok peterak Hasanah antara $0,43 \pm 0,02-0,44 \pm 0,02$.

Dari kedua kelompok tersebut hampir semuanya usaha memelihara ternak sapi potong peranakan Ongole (sapi PO). Ternak sapi PO yang dipelihara kelompok peternak rata-rata bobot badan jantan dewasa $>600 \mathrm{~kg}$, betina dewasa $>450 \mathrm{~kg}$. Rata-rata bobot badan induk dan jantan dewasa sebesr $220 \mathrm{~kg}-600 \mathrm{~kg}$. Pemeliharaan ternak sapi potong $\mathrm{PO}$, pada kelompok peternak adalah program dari Dinas Peternakan Kabupaten Sukabumi tahun 2007. Pertama pemeliharaan dengan cara gaduhan atau bagi hasil, saat ini sapi potong PO sudah milik peternak. Keunggulan ternak sapi PO reproduksi induknya setelah beranak cepat kembali normal, dan pejantannya memiliki kualitas semen yang baik. Sodiq dan Budiono (2012) menyatakan bahwa, untuk tujuan penggemukan kelompok peternak sapi potong mengusahakan bangsa Peranakan Ongole dan Sumba Ongole, Peranakan Simental dan Charolois. Rusdiana et al., (2010) menyatakan bahwa, kemungkinnya keunggulan lain dari ternak sapi PO, Peranakan Simental tahan terhadap panas, pertumbuhan relatif cepat.

Tabel 1. Karakteristik kelompok peternak sapi potong di Kecamatan Purabaya

\begin{tabular}{|c|c|c|c|c|}
\hline \multirow{2}{*}{ Urain } & \multicolumn{2}{|c|}{ Malingping (n-18) } & \multicolumn{2}{|c|}{ Hasanah (n-18) } \\
\hline & $\mathrm{I} \pm \mathrm{sd}$ & II + sd & $\mathrm{I}+\mathrm{sd}$ & $\mathrm{II}+\mathrm{sd}$ \\
\hline -Umur peternak/tahun & $44,67 \pm 0,34$ & $44,78 \pm 0,32$ & $44,5 \overline{6} \pm 0,28$ & $44,88 \pm 0,17$ \\
\hline -Pengalaman beternak/tahun & $22.31 \pm 0,10$ & $22,31 \pm 0,10$ & $22,43 \pm 0,10$ & $22,31 \pm 0,03$ \\
\hline -Tanggungan Keluarga/orang & $3,21 \pm 0,03$ & $3,22 \pm 0,02$ & $3,19 \pm 0,03$ & $3,23 \pm 0,02$ \\
\hline - Tenaga Kerja keluarga/orang & $1,0 \pm 0,05$ & $1,1 \pm 0,04$ & $1,0 \pm 0,05$ & $1,3 \pm 0,04$ \\
\hline -Luas lahan petani /ha & $0,42 \pm 0,18$ & $0,43 \pm 0,02$ & $0,43 \pm 0,02$ & $0,44 \pm 0,02$ \\
\hline
\end{tabular}

Sumber : Analisis data primer 2016 (diolah)

Tabel.2. Rata-Rata Kepemilikan Ternak Sapi Potong di Peternak

\begin{tabular}{lcccc}
\hline \multirow{2}{*}{ Uraian } & \multicolumn{4}{c}{ Kelompok peternak sapi potong Malingping } \\
\cline { 2 - 5 } & $\begin{array}{c}\text { Kelompok I skala } \\
\text { 2-3 ekor/rata-rata } \\
(\mathrm{n}-9)\end{array}$ & $\begin{array}{c}\text { Kelompok II skala 4-6 } \\
\text { ekor/rata-rata (n-9) }\end{array}$ & $\begin{array}{l}\text { Kelompok I-II } \\
\text { ekor/rata-rata } \\
\text { (n-18) }\end{array}$ & $\%$ \\
\hline Betina dewasa & $13(1,4)$ & $16(1,7)$ & $29(3,2)$ & 42,65 \\
Betina muda & $6(0,6)$ & $10(1,1)$ & $16(1,7)$ & 26,67 \\
Betina anak & $1(0,1)$ & $3(0,3)$ & $4(0,4)$ & 5,88 \\
Jantan dewasa & $3(0,3)$ & $6(0,6)$ & $9(1,0)$ & 13,23 \\
Pejantan muda & $2(0,2)$ & $4(0,4)$ & $6(0,6)$ & 8,82 \\
Jantan anak & $1(0,1)$ & $3(0,3)$ & $4(0,4)$ & 5,88 \\
Jumlah & $26(2,89)$ & $42(4,67)$ & $68(7,55)$ & 100 \\
\hline
\end{tabular}

Sumber : Analisis data primer 2016 (diolah) 


\section{Rataan Kepemilikan Sapi Potong di Peternak}

Kepemilikan ternak sapi potong pada umumnya betina induk dewasa. Jumlah kepemilikan ternak sapi potong pada setiap kelompok peternak sebagai penentu untuk peningkatan ekonomi keluarga. Peternak mengharapkan sekali, bahwa sapi potongnya mempunyai nilai jual yang tinggi, sehingga harapan peternak untuk meingkatkan kesehajteraannya tercapai. Rata-rata kepemiliakn ternak di masing-masing kemlopok terlihat pada Tabel 1 dan 2

Tabel 2, terlihat bahwa, kelompok peternak Malingping pada kelompok I rata-rata kepemilikan betina dewasa sebanyak 1,4 ekor/peternak dan betina muda sebanyak 0,6 ekor/peternak pada rata-rata pada kelompok II betina dewasa rata-rata sebanyak 1,7 ekor dan betina muda rata-rata sebanyak 1,1 ekor/peternak. Parameter yang diukur adalah nilai bibit, nilai jual bibit atau induk dan nilai jual anak. Nilai jumlah tenaga kerja keluarga petani, nilai estimasinya yang lebih tinggi adalah pemeliharaan pada kelompok II dengan skala 3 ekor induk betina. Kondisi ini sangat baik sekali, dan apabila diusahakan dengan menggunakan tenaga kerja keluarga, rata-rata sebanyak 1,0-1,1 orang/tahun tidak berlebih sesuai jumlah ternak yang dipelihara. Rata-rata induk menghasilkan anak sebanyak 0,2-06 ekor/induk/tahun per kelahiran, per jumlah induk yang dipelihara. Rata-rata jumlah kepemilikan ternak sapi potong yang dipelihara oleh kelompok peternak Malingpig, proporsi tertinggi betina dewasa sebesar $42,65 \%$, dan betina muda sebesar $26,67 \%$. Pada kelompok I dan II daya tampung ternak didominasi ternak sapi betina dewasa dan betina muda. Rata-rata kepemilikan ternak sapi potong terlihat pada Tabel.3.
Tabel 3, terlihat bahwa, kelompok peternak Hasanah pada kelompok I rata-rata betina dewasa sebanyak 1,4 ekor/peternak dan betina muda sebanyak 0,6 ekor/peternak. Pada kelompok II dengan skala kepemilikan ternak sapi potong betina dewasa rata-rata sebanyak 1,9 ekor/peternak dan betina muda sebanyak 0,7 ekor/peternak. Selian itu juga di ukur parameter jumlah bibit ternak sapi potong, anak sapi yang dijual, serta jumlah tenaga kerja keluarga petani. Estimasinya yang lebih tinggi pada kelompok II dengan skala 3 ekor. Kodisi ini sangat baik apabila diusahakan dengan menggunakan tenaga kerja keluarga, rata-rata sebanyak 1,0-1,3 orang/tahun tidak berlebih sesuai jumlah ternak yang dipelihara. Rata-rata induk menghasilkan anak sebanyak 0,3-06 ekor/induk/tahun per kelahiran anak per jumlah induk yang dipelihara, dan yang dihasilkan melalui perkawinan alami.

Rata-rata jumlah anak yang diperoleh hampir sama dari setiap peternak/tahun. Struktur populasi ternak sapi potong di kelompok peternak Hasanah, nampaknya proporsi tertinggi pada ternak sapi betina dewasa sebesar 43,28\%, dan betina muda sebesar 23,89\%. Kelompok I dan kelompok II tujuannya hampir sama membudidayakan untuk memperbanyak keturunannya anak, agar jumlah pemeliharaan lebih banyak dan bila dilihat dari daya tampung ternak di dominasi sapi betina dewasa, dan betina muda.

\section{Kelayakan Ekonomi Pada Usaha Sapi Potong di Peternak}

Hasil survei di lapangan menunjukkan, bahwa berdasarkan jumah ternak sapi potong yang terjual, pendapatan bersih akan terlihat, setelah semua biaya yang dikeluarkan dikurangi dengan pendapatan.

Tabel.3. Rata-rata kepemilikan ternak sapi potong di lokasi peternak

\begin{tabular}{lcccc}
\hline \multirow{2}{*}{ Uraian } & \multicolumn{4}{c}{ Kelompok peternak sapi potong Hasanah } \\
\cline { 2 - 5 } & $\begin{array}{c}\text { Kelompok I skala } \\
2-3 \text { ekor/rata-rata } \\
(\mathrm{n}-9)\end{array}$ & $\begin{array}{c}\text { Kelompok II skala 4-6 } \\
\text { ekor/rata-rata }(\mathrm{n}-9)\end{array}$ & $\begin{array}{c}\text { Kelompok I-II } \\
\text { ekor /rata-rata } \\
(\mathrm{n}-18)\end{array}$ & $\%$ \\
\hline Betina dewas & $13(1,4)$ & $17(1,9)$ & $29(3,2)$ & 43,28 \\
Betina muda & $6(0,6)$ & $7(0,7)$ & $16(1,8)$ & 23,89 \\
Betina anak & $1(0,1)$ & $3(0,3)$ & $4(0,4)$ & 5,97 \\
Jantan dewasa & $3(0,3)$ & $6(0,6)$ & $9(1,0)$ & 13,43 \\
Pejantan muda & $2(0,2)$ & $4(0,4)$ & $6(0,6)$ & 8,96 \\
Jantan anak & $2(0,2)$ & $3(0,3)$ & $6(0,4)$ & 5,97 \\
Jumlah & $27(3,00)$ & $40(4,44)$ & $67(7,44)$ & 100 \\
\hline
\end{tabular}

Sumber : Analisis data primer 2016 (diolah) 
Pendapatan peternak atan petani akan terlihat apabila dihitung semua biaya dan pendapatan setelah panen atau menjual hasil usahanya (Amik et al. 2006). Menurut Rusdiana dan Adawiyah (2013) bahwa, keuntungan yang diperoleh peternak akan terlihat dengan jelas, apabila pemeliharaan sapi potong dihitung berdasarkan jumlah ternak yang dipelihara dan ternak yang dijual. Pengeluaran biaya untuk pakan oleh peternak dimasukan kedalam tenaga kerja keluarga. Menurut Winarso et al. (2005); Rusdiana et al. (2010) dan Atmakusuma et al. (2014) bahwa, dengan menggunakan metode analisis ekonomi, angka banding antara nilai skala usaha dan biaya produksi akan terlihat nilai keuntungannya. Rusdiana dan Soeharsono (2017) dan Rusdiana et al., (2017) menyatakan bahwa, keuntungan akan dapat diketahui oleh setiap peternak apabila usaha tersebut sudah dilakukan selama satu tahun.

\section{Estimasi Hasil Kelayakan Usaha Sapi Potong di Peternak}

Keuntungan merupakan hasil dari perhitungan ekonomi dari kelayakan usaha ternak sapi potong pada kelompok peternak Malingpig dan Hasanah. Dapat disimpulkan dengan memelihara ternak sapi potong 2-3 ekor, peternak dapat memperoleh keuntungan setiap bulan/tahun. Apabila biaya yang dikeluarkan oleh peternak sudah pasti tidak berlebih dalam pengeturan usahanya. Perhitungan tersebut dengan diestimasikan pada kelompok peternak untuk memperoleh pedet, asumsi ini jarang terjadi sebab biasanya 1 ekor ternak sapi betina dewasa akan menghasilkan pedet minimal 1 ekor per dua tahun. Pada periode berikutnya biasanya modal yang dikeluarkan oleh kelompok peternak akan semakin berkurang, karena biaya kandang tidak dikeluarkan kembali. Setiap kelompok peternak mengestimasi usahanya lebih mendalam, maka akan ada sumber pendapatan lain seperti kotoran sapi yang dihasilkan.

Estimasi dari beberapa faktor produksi pada usaha ternak sapi potong diantaranya: bibit, kandang, pakan, tenaga kerja dan biaya, kesehatan ternak, estimasi ini dapat dirinci sebagai berikut. Kelompok peternak Malingping, sebanyak 2 ekor, bibit betina produktif, rata-rata bobot badan awal sebanyak
210 kg/ekor, harga sebesar Rp.63.500/kg, bobot hidup bibit sebesar Rp.13.335.000,-/ekor x 2 ekor atau sebesar Rp.26.670.000,-. Pada kelompok II skala sebanyak 3 ekor betina produktif dengan bobot badan awal sebanyak $212 \mathrm{~kg}$, harga daging sebesar Rp 63.500/kg, bobot hidup sebesar Rp13.462.000/ekor x 3 ekor sebesar Rp40.386.000, sebagai modal awal investasi usaha ternak sapi potong pada kelompok peternak. Sedangkan untuk kelompok peternak sapi potong Hasanah sebanyak 2 ekor bibit betina induk produktif, bobot badan sebanyak $211 \mathrm{~kg}$, harga bobot badan hidup sebesar Rp 63.500/ kg atau sebesar $\mathrm{Rp}$ 13.398.500 x 2 ekor atau sebesar $\mathrm{Rp}$ 26.797.000,- sebagai modal invetasti usaha awal pada kelompok I.

Investasi pada kelompok II Hasanah sebanyak 3 ekor, bobot badan awal sebesar $212,5 \mathrm{~kg}$, harga bobot badan hidup sebesar Rp 63.500/kg atau sebesar Rp 13.493.750/ ekor x 3 ekor sebesar Rp 40.481.250 sebagai modal awal investasi. Harga jual ternak sapi jantan anak dan betina anak, rata-rata umur sekitar 3-5 bulan, harga jual sebesar $\mathrm{Rp}$ 3.000.000/ekor. Pendapatan kelompok peternak Malingping dan Hasanah, dihitung berdasarkan satu tahun, secara ekonomi B/C. Masingmasing skala usaha dianalisa dan diperjelas melalui kelompok I skala 2-3 ekor dan kelompok II, skala 4-6 ekor. Estimasi keuntungan masing-masing kelompok peternak skala 2-3 ekor induk betina produktif terlihat pada Tabel 4.

Tabel 4, terlihat bahwa keuntungan bersih kelompok peternak Malingping pada kelompok I, pemeliharaan skala 2 ekor induk sebesar Rp 2.078.000/ tahun/peternak dan B/C ratio 1,06. Keuntungan bersih pada kelompok II pemeliharaan skala 3 ekor iduk sebesar $\mathrm{Rp}$ 5.799.500/tahun/peternak, $\mathrm{B} / \mathrm{C}$ ratio 1,12 . Pemeliharaan skala 3 ekor induk betina produktif sangat ekonomis, efektif dan efisien. Analisis ekonomi usaha ternak sapi potong pada kelompok peternak Hasanah terlihat pada Tabel 5

Tabel 5, terlihat bahwa keuntungan bersih kelompok peterrnak sapi potong Hasanah pada kelompok I, pemeliharaan skala 2 ekor induk sebesar Rp 2.384.000/tahun/ peternak dan $\mathrm{B} / \mathrm{C}$ ratio 1,05 . 
S. Rusdiana, L. Praharani, D.A. Kusumaningrum : Perbaikan Skala Usaha Sapi Potong...

Tabel 4.Analisis ekonomi usaha sapi potong kelompok Malingping

\begin{tabular}{lcc}
\multicolumn{1}{c}{ Kelmpopok peternak sapi potong Malingping } & $\begin{array}{c}\text { Kelompok I } \\
(\mathrm{n}-9)\end{array}$ & $\begin{array}{c}\text { Kelompok II } \\
(\mathrm{n}-9)\end{array}$ \\
\hline -Nilai bibit betina, harga bobot badan hidup @ Rp.63.500/kg & $211 \mathrm{~kg}$ & $212,5 \mathrm{~kg}$ \\
-Nilai kandang/unit & 700.000 & 2.100 .000 \\
-Nilai jumlah tenaga keja petani /orang & 1,0 & 1,1 \\
-Nilai harga bibit kelompok I, 2 ekor dan II, 3 ekor & 26.670 .000 & 40.386 .000 \\
-Nilai penyusutan kandang /5 tahun & 140.000 & 420.000 \\
-Nilai upah tenaga kerja petani Rp.15.000/ (360 hari) & 5.400 .000 & 5.940 .000 \\
-Nilai pembelian ampas tahu 1 kg/hari @ Rp.500/kg/tahun & 360.000 & 540.000 \\
-Nilai pembelian hijuan pakan ternak (tidak beli) ed libitum & 0 & 0 \\
Jumlah pengeluaran/tahun & 32.570 .000 & 47.286 .000 \\
-Nilai jual akhir bobot badan betina @ Rp.66.500 & $256 \mathrm{~kg}$ & $258 \mathrm{~kg}$ \\
-Nilai, jumlah kelompok I, 2 ekor dan II, 3 ekor & 34.048 .000 & 51.471 .500 \\
-Nilai jual anak rata-rata umur 3-5 bualn @ Rp.3.000.000 & 0,3 & 0,6 \\
-penjualan anak betina dan jantan kelompok I dan II & 600.000 & 1.800 .000 \\
Jumlah pendapatan & 34.648 .000 & 53.271 .000 \\
-Estimasi pendapatan/tahun & 2.078 .000 & 5.799 .500 \\
-Nilai B/C ratio & 1,06 & 1,12 \\
\hline Sumber : Analisis data primer 2016 (dilah) & &
\end{tabular}

Sumber : Analisis data primer 2016 (diolah)

Tabel 5. Analisis ekonomi usaha sapi potong kelompok Hasanah

\begin{tabular}{lcc}
\multicolumn{1}{c}{ Kelmpopok peternak sapi potong Hasanah } & $\begin{array}{c}\text { Kelompok } \\
\text { I (n-9) }\end{array}$ & $\begin{array}{c}\text { Kelompok II } \\
(\mathrm{n}-9)\end{array}$ \\
\hline -Nilai bibit betina, harga bobot badan hidup @ Rp.63.500/kg & $211 \mathrm{~kg}$ & $212,5 \mathrm{~kg}$ \\
-Nilai kandang /unit & 700.000 & 2.100 .000 \\
-Nilai jumlah tenaga keja petani /orang & 1,0 & 1,3 \\
-Nilai harga bibit kelompok I, 2 ekor, kelompok II, 3 ekor & 26.797 .000 & 40.481 .250 \\
-Nilai penyusutan kandang /5 tahun & 140.000 & 420.000 \\
-Nilai upah tenaga kerja petani Rp.15.000/ (360 hari) & 5.400 .000 & 7.020 .000 \\
-Nilai pembelian ampas tahu 1 kg/hari @ Rp.500/kg/tahun & 360.000 & 540.000 \\
-Nilai pembelian hijuan pakan ternak ed libitum & 0 & 0 \\
Jumlah pengeluaran/tahun & 32.697 .000 & 48.461 .250 \\
-Nilai jual akhir bobot badan betina @ Rp.66.500 & $257 \mathrm{~kg}$ & $259 \mathrm{~kg}$ \\
-Nilai, jumlah kelompok I, 2 ekor dan II, 3 ekor & 34.181 .000 & 51.670 .500 \\
-Nilai jual anak rata-rata umur 3-5 bualn @ Rp.3.000.000 & 0,3 & 0,6 \\
-penjualan anak betina dan jantan kelompok I dan II & 900.000 & 1.800 .000 \\
Jumlah pendapatan & 34.081 .000 & 53.470 .500 \\
-Estimasi pendapatan/tahun & 2.384 .000 & 5.009 .250 \\
-Nilai B/C ratio & 1,05 & 1,10 \\
\hline Sumber: Anlisis data primer 2016 (diolah) & &
\end{tabular}

Sumber : Analisis data primer 2016 (diolah)

Keuntungan bersih pada kelompok II, pemeliharaan skala 3 ekor induk sebesar Rp 5.009.250/tahun dengan $\mathrm{B} / \mathrm{C}$ ratio 1,10 . Hasil penelitian Rusdiana et al., (2016b) usaha pemeliharaan sapi potong dengan cara digembalakan dilahan perkebunan sawit dan karet peternak mendapat keuntungan sebesar Rp 3.185.000/tahun dengan B/C 1,2. Hampir sesuai dengan hasil penelitian Rusdiana dan Soeharsono (2017a) usaha pembesaran sapi potong dengan cara pemberian pakan lokal peternak mendapat keuntungan sebesar Rp $2.260 .000 /$ periode dengan B/C 1,6. Artinya kelompok peternak sapi potong Malingping dan Hasanah di Kecamatan Purabaya dengan pemeliharaan skala >3 ekor induk betina produktif sangat ekonomis, efektif dan efisien, dan secara analisis ekonomi finansial layak. Peningkatan pendapatan usaha sapi potong pada kelompok peternak Malingping dan Hasanah, adalah dengan penambahan jumlah usaha yang diperlukan sumberdaya lahan dan tenaga kerja peternak tidak bertambah. 


\section{KESIMPULAN DAN SARAN}

\section{Kesimpulan}

Kondisi lokasi penelitian di Kecamatan Purabaya Kabupaten Sukabumi, Propinsi Jawa Barat sangat mendukung untuk perkembangan usaha ternak sapi potong. Keuntungan bersih pada kelompok peternak Malingping dari skala 2 ekor induk menjadi 3 ekor induk sebesar Rp 2.078.000/tahun naik menjadi sebesar Rp $5.799 .500 /$ tahun atau sebesar $65,13 \%, \mathrm{~B} / \mathrm{C}$ ratio 1,06-1,12. Keuntungan bersih pada kelompok peternak Hasanah dari skala 2 ekor induk menjadi skala 3 induk ekor sebesar Rp 2.384.000/tahun naik menjadi sebesar Rp $5.009 .250 /$ tahun, atau sebesar $64.18 \%, \mathrm{~B} / \mathrm{C}$ raio 1,05-1,10. Bila kelompok peternak sapi potong Malingping dan Hasanah memelihara skala >3 ekor induk betina produktif per peternak, sangat ekonomis, efektif dan efisien, secara ekonomi finansial layak untuk dusahakan kembali.

\section{Saran}

Kelompok peternak perlu dukungan dan dipacu dalam usaha ternaknya, sehingga berdampak terhadap penigkatan populasi sapi potong. Kabupaten Sukabumi secara umum dapat diarahkan pada orientasi pengembangan usaha ternak sapi potong melalui pembibitan, kemudian dapat dilanjutkan kepada usaha agribisnis. Kelompok peternak dapat diarahkan kepada peningkatan kesadaran serta rasa percaya diri, melalui peningkatan pengetahuan dan keterampilan usaha. Melalui implikasi dan kebijakan Pemerintah, diharapkan peternak dapat meningkatkan pendapatan dan kesejahteraan serta status sosial ekonomi terjamin. Dengan dukungan kelembagaan kelompok peternak sapi potong yang dinamis berjalan dengan baik, diharapkan kepada kelompok peternak sapi potong dapat mempertahankan ternaknya.

\section{DAFTAR PUSTAKA}

Ahmad, S.N., D.D. Siswansyah, dan O.K.S. Swastika. 2004. Kajian sistem usaha ternak sapi potong di Kalimantan Tengah. Jurnal Pengkajian dan Pengembangan Teknologi Pertanian 7(2): 155-170.
Amik.K. Dan Firmansyah.M.A. 2006. Kajian teknologi usahatani jagung dilahan kering Kalimantan Selatan. Pusat Penelitian dan Pengembangan Sosial Ekonomi Pertanian, Badan Litbang Pertanian. Jurnal Pengkajian dan Pengembangan Teknologi Pertanian, Maret 2006, 8(1):39-54

Atmakusuma, J, Harmini dan Ratna W. 2011. Mungkinkah swasembada daging terwujud. Jurnal Risalah Kebijakan Pertanian dan Lingkungan, Departemen Agribisnis, Fakultas Ekonomi dan Manajemen IPB Bogor 16680, Jurnal Ekonomi Pertanian, Agustus 2011,1(2):105-109

Adawiyah, R. A., Rusdiana, S., dan M, Ichwan 2016. Diversifikasi usaha pertanian dalam rangka antisipasi MEA kebutuhan pangan di Indonesia. Prosiding Seminar Nasional membangun pertanian moderen, Balai Besar Pengkajian dan Pengembangan Teknologi Pertanian, Jambi 31 Mei 1 Juni 2016, hal.11571166.

Adawiyah, R. A., dan Rusdiana, S. 2016. Usahatani tanaman pangan dan peternakan dalam analisis ekonomi di peternak. Jurnal Riset Agribisnis dan Peternakan Desember 2016,1(2):3749

Dinas Pertanian dan Peternakan Kabupaten Sukabumi Propinsi Jawa Barat. 2016. Luas lahan wilayah Kabupaten Sukabumi dalam angka luas pekarangan perkampungan dan rumah, dalam buku Statistik Pertanian dan Peternakan tahun 2016, Desember 2016, hal. 1-67.

Dewi.F. dan Mairika.L.2008. Pemanfaatan limbah pertanian sebagai pakan ruminansia pada peternakan rakyat di Kecamatan Rengat Barat Kabupaten Indragiri Hulu Pakan Baru Riau. Jurnal Peternakan, Februari 2008, 5(1):28-37.

Dwiyanto, K. 2008. Pemanfaatan sumberdaya lokal dan inovasi teknologi dalam mendukung pengembangan sapi potong di Indonesia Jurnal Pengembangan 
Inovasi Pertanian Nopember 2008, I (3):173-188.

Dewi. D., Harianto, Sjafri. M., dan Nunung. K. 2010. Peran pengembangan sumber daya manusia dalam peningkatan pendapatan rumah tangga petani di Daerah Istimewa Yogyakarta. Forum Pascasarjana, IPB. Juli 2010, 33(3):155177.

[Dirjen PKH]. Direktorat Jenderal Peternakan dan Kesehatan Hewan, Kementerian Pertanian. 2016. Pedoman pelasanaan Upaya Khusus Sapi Induk Wajib Bunting (Upsus SIWAB). Jakarta [ID] Kementerian Pertanian 1-56

Gustimulyanti Dynasti, Sondi Kuswaryan dan Hasni Arief. 2016. Penentuan skala usahaternak domba sebagai usaha pokok rumah tangga perdesaan (kasus di wilayah kerja koperasi peternak serba usaha iungmukti kabupaten sukabumi), Jurnal Peternakan Universitas Pajajaran Bandung, Bandung Juni 2016, 1(2):1-14

Hoddi.H.A., M.B.Rombe dan Fahrul. 2011. Analisis pendapatan peternakan sapi potong di Kecamatan Tanete Rilau, Kabupaten Baru, Jurnal Agribisnis Unhas September 2011,10(3):98-109.

[Kementan] Kementerian Pertanian. 2015. Peraturan dan Keputusan Menteri Pertanian Nomor 71/Kpts/OT.210/ 1/2002. 2012. Tentang organisasi dan tata kerja lingkup Kementerian Pertanian, Badan Litbang Pertanian dan Balai Penelitian Ternak.

[Kementan] Kementerian Pertanian. 2018. Indonesia akan ekspor 800 ribu ternak domba pada tahun 2018 [Internet] [Didownlot tgl, 3 Maret 2018]. Tersedia dari

http://id.beritasatu.com/agribusiness/artik el/2018-ri-akan-ekspor-800-ribu-sapi potong//149121.

Ilham, U., Hermanto, S., dan D,S, Priyarsono. 2008. Efektivitas kebijakan harga pangan terhadap ketahanan pangan, Jurnal Agro
Ekonomi PSEKP, Mei 2008, Vol. 24(2):157-177.

Muzayyanah, M.A.U., S.Nartini dan R.Widiati. 2016. Analisis keputusan rumah tangga dalam mengkonsumsi pakan sumber protein hewani asal ternak dan non ternak: Studi Kasus di Propinsi D.I. Yogyakarta. Buletin Peternakan Fakultas Peternakan Universitas Gajah Mada, Mei 2017,41(2):203-211.

Riszqina, L. Jannah, Isbandi, E.Rianto, dan S.I. Santoso.2011. Analisis pendapatan peternak sapi potong dan sapi bakalan karapan di pulau sapudi Kabupaten Sumenep Jurnal Unhas, JITP Juli 2011, 1(3):78-86.

Rusdiana, S., dan L, Praharani. 2015. Peningkatan usaha ternak ruminansia melalui diversifikasi tanaman pangan, analisis pendapatan peternak. Jurnal Agroekonomika Jurnal Penelitian Sosial Ekonomi dan Kebijakan Pertanian, Vol. April 2015, .4(1):80-95

Rusdiana S., B. Wibowo dan L. Praharani. 2010. Penyerapan Sumberdaya manusia dalam analisis fungsi usaha penggemukan sapi potong rakyat di pedesaan. Prosiding Seminar Nasional Teknologi Peternakan dan Veteriner. Pusat Penelitian dan Pengembangan Peternakan, Agustus 2010, hal, 20-29.

Rusdiana, S., dan A. Bamualim. 2010. Memacu peningkatan populasi sapi potong dalam upaya peningkatan produksi daging. 2010. Seminar Nasional Balai Besar Pengkajian dan Pengembangan Teknologi Pertanian, Tim: Syahrul.B., Agus.M., Argono.R.Setioko., acmat.H., dan Erizal.J. Bogor, 15-16 oktober 200. Hal. 168-177.

Rusdiana,S dan Cut.R.Adawiyah. 2013. Permasalahan ekonomi dan sistem perekonomian hasil produksi pertanian di Indonesia. Activita Jurnal Pemberdayaan Mahasiswa dan masyarakat, Agustus 2013, 3(2):263280. 
Rusdiana, S., dan C.R. Adawiyah. 2013. Analisis ekonomi dan prospek usaha tanaman dan ternak dilahan perkebunan kelapa. Jurnal Sosial Ekonomi Pertanian dan Agribisnis SEPA, September 2013, 10(1):118-131.

Rusdiana, S., U., Adiati dan R. Hutasoit. 2016a. Analisis ekonomi usaha ternak sapi potong berbasis agroekosistem di Indonesia. Jurnal Sosial Ekonomi dan Kebijakan Pertanian. Jurnal Agroekonomika Oktober 2016, 5(2):137149.

Rusdiana, S., R. Hutasoit dan J. Sirait. 2016b. Analisis ekonomi usaha sapi potong di lahan perkebunan sawit dan karet. Program Studi Agribisnis Fakultas Pertanian, UNS Jurnal Sepa. Pebruari 2016, 12(2):146-155

Rusdiana, S and Soeharsono.2017a. Farmer group performance bali cattle in luwu district east: the economic analysis. The International Journal of Trovical Veterinery and Biomedical Research, The Faculty of Veterinery Medicine Syiah Kuala University, May 2017, 2(1):18-29.

Rusdiana, S dan Soeharsono. 2017b. Analysis of business efficiency level of beer catle in Banggal District of Central Sulawesi. Bulletin of Animal Science, Pebruari 42(1):72-79

Rusdiana, S., R. Hutasoit and T. R. Ferasyi. 2017. Beef cattle business by profit sharing in farmers on plantation area. Proceedings of the $7^{\text {th }}$ AIC-ICRM health and life Sciences. The Annual International Conperence 2017 Syiah Kuala University, October 18-20, 2017. Banda Aceh Indonesia, Pp. 293-299.

Rusdiana, S dan Soeharsono.2017b.Program Siwab untuk meningkatkan populasi saapi potong dan nilai ekonomi usaha ternak PSEKP, Forum Agro Ekonomi, Desember 2017, 35(2):125-137.

Rusdiana,S, Ismail, R. Silaiman, Amiruddin, R, Daud, Zaenuddin and M. Sabri. 2018. The effor of beef needs supplying for coming years in Indonesia. Syiah Kuala University Darusalam Banda Aceh. Jurnal International Trop.Vet. Biomeds . Res. Syiah Kuala University Darusalam Banda Aceh. Mey 2018, 3(1):48-59.

Suryana.2010. Pengembangan usaha ternak sapi potong berorientasi agribisnis dengan pola kemitraan. Jurnal Litbang Pertanian, Juli 2010, 28 (1):29-39

Sodiq, A. dan M.Budiono.2012. Produktivitas sapi potong pada kelompok tani ternak di pedesaan. Jurnal Agripet April 2012, Vol 12(1):28-33

Winarso, B., R. Sajuti, dan C. Muslim. 2005. Tinjauan ekonomi ternak sapi potong di Jawa Timur. PSEKP, Jurnal, Forum Penelitian Agro-Ekonomi Juli 2005, 23(1): 61-71. 